\title{
Studi retrospektif erupsi obat alergik di RS dr. M. Djamil Padang periode Januari 2014 - Desember 2016
}

\author{
Meligasari L. Gaya, Gardenia Akhyar
}

\begin{abstract}
Abstrak
Latar belakang: Erupsi obat alergik (EOA) dapat terjadi pada semua usia dengan berbagai manifestasi klinis. Obat penyebab terbanyak EOA umumnya adalah golongan antibiotik dan anti-konvulsan. Terdapat peningkatan kasus EOA di RSUP dr. M. Djamil Padang dari tahun ke tahun. Tujuan penelitian: Mengetahui profil EOA berdasarkan jumlah dan variasi kasus, usia, jenis kelamin, serta obat terbanyak yang dicurigai menyebabkan EOA di RSUP dr.M.Djamil Padang periode Januari 2014 - Desember 2016. Metode: Penelitian dilakukan secara retrospektif berdasarkan rekam medis pasien rawat inap dan rawat jalan di RSUP DR.M.Djamil Padang periode Januari 2014 - Desember 2016. Hasil: Selama periode Januari 2014 - Desember 2016 didapatkan kasus EOA sebanyak 179 kasus. Tipe makulopapular merupakan EOA terbanyak (26,25\%), diikuti oleh Sindrom Steven Johnson (SSJ) $(24,02 \%)$ dan eritroderma (24,02\%). Kelompok usia 25 - 44 tahun $(37 \%)$ merupakan usia terbanyak pada semua tipe EOA. Berdasarkan jenis obat penyebab, cefadroxil merupakan obat penyebab terbanyak pada kelompok makulopapular dan eritroderma, sedangkan karbamazepin merupakan obat penyebab terbanyak penyebab SSJ. Kesimpulan: Pada penelitian ini, antibiotik dan anti-konvulsan merupakan obat tersangka terbanyak yang menyebabkan EOA, sama seperti banyak penelitian sebelumnya. Antibiotik (cefadroxil) merupakan obat penyebab terbanyak pada kelompok makulopapular dan eritroderma, sedangkan anti-konvulsan (karbamazepin) merupakan obat penyebab terbanyak pada kelompok SSJ.
\end{abstract}

Kata kunci: makulopapular, eritroderma, sindrom Steven Johnson

\begin{abstract}
Background: Cutaneous drug eruptions (CDRs) can occur at any age with various clinical manifestations. The most common suspected drugs cause of CDR are the antibiotic and anti-convulsant groups. There is an increasing case in CDRs in dr. M. Djamil General Hospital Padang from year to year. Aim: Knowing the CDR profile based on the number and variation of cases, age, sex, and most culprit drugs suspected to cause CDR at Dr.M.Djamil Padang in January 2014 - December 2016. Method: The study was conducted retrospectively based on the medical records of inpatients and outpatients in RSUP DR.M.Djamil Padang period January 2014 - December 2016. Result: During the period of January 2014 - December 2016, there were 179 cases of CDR. The maculopapular type is the commonest CDR $(26,25 \%)$, followed by Steven Johnson Syndrome (SSJ) $(24,02 \%)$ and erythroderma $(24,02 \%)$. The age group of $15-24$ years (37\%) is the most age in all CDR types. Based on culprit drugs, cefadroxil is the most suspected drug in the maculopapular and erythrodermic groups, whereas carbamazepine is the most suspect drug cause of SJS. Conlusion: In this study, antibiotics and anti-convulsants are the most suspect drugs that cause CDR, just as with many previous studies. Antibiotics (cefadroxil) is the most suspected drug in the maculopapular and erythrodermic groups, while anti-convulsant (carbamazepine) is the most suspect drug in the SJS group.
\end{abstract}

Keywords: maculopapular, erythroderma, Stevens Johnson syndrome

Affiliasi penulis : Bagian IImu Kesehatan Kulit dan Kelamin RSUP dr. M. Djamil Padang/Fakultas Kedokteran Universitas Andalas, Padang Korespondensi : Meligasari L. Gaya [miadek.md@gmail.com] Telp: 0751-810256

\section{PENDAHULUAN}

Erupsi obat alergik (EOA) merupakan reaksi alergi pada kulit dan/atau mukokutan yang disebabkan oleh pemberian obat secara sistemik. Kelainan ini merupakan manifestasi klinis yang sering dijumpai di bidang dermatologi, dengan tingkat keparahan yang bervariasi, mulai dari yang ringan hingga berat dan mengancam nyawa, dan merupakan bentuk yang paling sering ditemukan dari reaksi alergi obat. ${ }^{1,2}$ Erupsi obat alergik diperkirakan mengenai sekitar 2$6 \%$ orang yang mendapatkan pengobatan. ${ }^{3}$ Berbagai jenis obat telah dilaporkan sebagai penyebab EOA, namun golongan antibiotik (sulfonamid), antikonvulsan, allopurinol, dan obat anti inflamasi nonsteroid (OAINS) merupakan obat penyebab terbanyak. ${ }^{1,2,4}$ Spektrum manifestasi klinis EOA meliputi bentuk exanthematous/makulopapular, urtikaria, pustular, dan bulosa. Bentuk makulopapular merupakan bentuk EOA yang paling sering dilaporkan dari berbagai literatur. Diagnosis yang tepat dari tipe reaksi dapat membantu memperkecil kemungkinan penyebab, karena obat yang berbeda sering berhubungan dengan tipe reaksi yang berbeda pula. ${ }^{1}$

\section{METODE}

Penelitian dilakukan secara retrospektif dengan mendata rekam medis pasien rawat inap dan rawat jalan di RSUP DR.M.Djamil Padang periode Januari 2014 - Desember 2016.

\section{HASIL}

Selama periode Januari 2014 - Desember 2016 didapatkan kasus EOA sebanyak 179 kasus. Tipe makulopapular merupakan EOA terbanyak, diikuti oleh Sindrom Steven Johnson (SSJ) dan eritroderma (tabel 1). 
Tabel 1. Distribusi Tipe Erupsi Obat Alergik di RSUP dr. M. Djamil Periode Januari 2014 - Desember 2016.

\begin{tabular}{|c|c|c|c|c|c|c|}
\hline \multirow[t]{2}{*}{ No } & \multirow{2}{*}{ Tipe EOA } & \multicolumn{3}{|c|}{$\mathrm{n}$} & \multirow[t]{2}{*}{ Total } & \multirow[t]{2}{*}{$\%$} \\
\hline & & 2014 & 2015 & 2016 & & \\
\hline 1 & Urtikaria & 1 & 2 & 0 & 3 & $1,67 \%$ \\
\hline 2 & Makulopapular & 15 & 12 & 20 & 47 & $26,25 \%$ \\
\hline 3 & Eritroderma & 13 & 14 & 16 & 43 & $24,02 \%$ \\
\hline 4 & AGEP & 10 & 5 & 1 & 16 & $8,93 \%$ \\
\hline 5 & $\begin{array}{l}\text { Fixed } \\
\text { Eruption }\end{array}$ & 1 & 5 & 2 & 8 & $4,46 \%$ \\
\hline 6 & SSJ & 5 & 16 & 22 & 43 & $24,02 \%$ \\
\hline 7 & $\begin{array}{l}\text { SSJ overlap } \\
\text { TEN }\end{array}$ & 1 & 1 & 5 & 7 & $3,91 \%$ \\
\hline 8 & TEN & 4 & 3 & 4 & 11 & $6,14 \%$ \\
\hline 9 & $\begin{array}{l}\text { Drug induced } \\
\text { vasculitis }\end{array}$ & 0 & 1 & 0 & 1 & $0,55 \%$ \\
\hline Total & & 50 & 59 & 70 & 179 & $100 \%$ \\
\hline
\end{tabular}

Berdasarkan jenis kelamin, secara keseluruhan EOA lebih sering mengenai laki-laki dibandingkan perempuan (tabel 2), dengan perbandingan 1.03:1.

Tabel 2. Distribusi Jenis Kelamin dan Tipe EOA

\begin{tabular}{llcc}
\hline No & Tipe EOA & L & P \\
\hline 1 & Urtikaria & 0 & 3 \\
2 & Makulopapular & 26 & 21 \\
3 & Eritroderma & 26 & 17 \\
4 & AGEP & 2 & 7 \\
5 & Fixed Drug Eruption & 10 & 5 \\
6 & SSJ & 15 & 28 \\
7 & SSJ overlap TEN & 4 & 3 \\
8 & TEN & 7 & 4 \\
9 & Drug induced vasculitis & 1 & 0 \\
Jumlah & & 91 & 88 \\
\hline
\end{tabular}

Berdasarkan kelompok usia, didapatkan EOA terbanyak mengenai kelompok usia 25 - 44 tahun (37\%) dan paling sedikit kelompok usia 1-4 tahun (tabel 3).

Tabel 3. Distribusi Usia dan Tipe EOA

\begin{tabular}{|c|c|c|c|c|c|c|c|}
\hline No & $\begin{array}{c}\text { Jenis Erupsi } \\
\text { Obat }\end{array}$ & $\begin{array}{l}1- \\
4\end{array}$ & $\begin{array}{l}5- \\
14\end{array}$ & $\begin{array}{l}15- \\
24\end{array}$ & $\begin{array}{l}25- \\
44\end{array}$ & $\begin{array}{l}45- \\
64\end{array}$ & $\begin{array}{l}> \\
65\end{array}$ \\
\hline 1 & Urtikaria & 1 & & 1 & & 2 & \\
\hline 2 & Makulopapular & 1 & 4 & 10 & 19 & 11 & 2 \\
\hline 3 & Eritroderma & & 1 & 3 & 20 & 14 & 5 \\
\hline 4 & PEGA & & & & 5 & 4 & \\
\hline 5 & $\begin{array}{l}\text { Fixed Drug } \\
\text { Eruption }\end{array}$ & 1 & 5 & 2 & 3 & 3 & 1 \\
\hline 6 & SSJ & 1 & 5 & 7 & 16 & 12 & 2 \\
\hline 7 & $\begin{array}{l}\text { SSJ overlap } \\
\text { TEN }\end{array}$ & 1 & 2 & & 3 & 1 & \\
\hline 8 & TEN & 1 & 3 & 6 & 1 & & \\
\hline 9 & $\begin{array}{l}\text { Drug induced } \\
\text { vasculitis }\end{array}$ & & & 1 & & & \\
\hline \multicolumn{2}{|c|}{ Jumlah } & 6 & 20 & 30 & 67 & 47 & 10 \\
\hline
\end{tabular}

\section{PEMBAHASAN}

Berdasarkan jenis EOA, didapatkan tipe makulopapular merupakan EOA terbanyak, diikuti oleh sindrom Steven Johnson (SSJ) dan eritroderma. Hasil ini sesuai dengan literatur yang menyebutkan bahwa bentuk makulopapular merupakan EOA yang paling sering ditemukan, meliputi $\pm 95 \%$ reaksi kulit. ${ }^{1}$ Suatu studi retrospektif yang dilakukan oleh Pang JYY, dkk (Hong Kong, 2015) ${ }^{5}$ menemukan dari 76 pasien dengan EOA, tipe makulopapular merupakan tipe terbanyak $(68,3 \%)$, diikuti oleh tipe urtikaria $(14,5 \%)$, PEGA (4\%), dan FDE (4\%). Akan tetapi, hasil yang berbeda dilaporkan oleh Al-Raaie F,dkk.(Oman, $2008)^{2}$ yang menemukan dari 100 orang pasien EOA, tipe urtikaria merupakan tipe terbanyak, diikuti oleh FDE dan makulopapular.

Berdasarkan obat yang dicurigai sebagai penyebab, cefadroxil merupakan obat penyebab terbanyak pada kelompok makulopapular dan eritroderma. Cefadroxil merupakan antibiotik golongan sefalosporin yang biasa digunakan pada berbagai macam infeksi, seperti infeksi kulit akibat kuman Streptococcus atau Staphylococcus, infeksi saluran nafas seperti faringitis dan tosilitis, serta infeksi saluran kemih. Selain itu, obat tersebut dijual bebas dan mudah didapatkan sendiri. Hal tersebut yang kemungkinan menyebabkan obat ini menjadi obat tersering yang ditemukan pada penelitian ini.

Selain cefadroxil, karbamazepin ditemukan sebagai obat terbanyak penyebab SSJ. Karbamazepin merupakan golongan anti-konvulsan yang biasa dipakai pada penyakit-penyakit seperti epilepsi, neuralgia trigeminal, neuralgia diabetes mellitus, neuralgia glosofaringeal, dan neuralgia post herpetik. ${ }^{4}$ Pada penelitian ini, seluruh pasien kami mendapatkan karbamazepin untuk gangguan psikosomatis.

Berdasarkan data dari European SCAR (EuroScar), dua obat tersering penyebab SSJ/TEN adalah karbamazepin dan allopurinol. Insiden SSJ/TEN yang disebabkan oleh karbamazepin dan fenitoin di Asia Tenggara dilaporkan sebesar 26\%, lebih tinggi secara signifikan dibandingkan di Eropa (12\%). ${ }^{6}$ Studi retrospektif oleh Rahima S,dkk (India, $2017)^{7}$ juga menemukan obat penyebab SSJ terbanyak adalah karbamazepin (32\%).

Terdapatnya pengaruh genetik juga diketahui memiliki peran penting untuk terjadinya SSJ/TEN yang disebabkan oleh karbamazepin. Hubungan yang kuat ditemukan antara HLA-B*1502 dengan kasus SSJ/TEN akibat karbamazepin pada populasi Han Chinese di Taiwan dan beberapa negara Asia lainnya, seperti China, Hongkong, Thailand, dan Malaysia. ${ }^{8,9} \mathrm{Di}$ Indonesia, Khosama H dkk. (Makasar, 2017) dalam penelitiannya juga menemukan hubungan yang kuat antara HLA-B*1502 dengan kejadian SSJ/TEN, dimana HLA-B*1502 ditemukan pada $57,1 \%$ pasien SSJ/TEN dibandingkan $26,4 \%$ kontrol sehat dengan hasil yang bermakna secara statistik. ${ }^{9}$ Pada penelitian ini hubungan tersebut belum dapat disimpulkan dan memerlukan penelitian lebih lanjut.

Berdasarkan jenis kelamin, secara keseluruhan EOA lebih sering mengenai laki-laki dibandingkan perempuan dengan perbandingan 1.03:1. Hasil ini serupa dengan hasil penelitian Neupane S,dkk.(Nepal, 2012) ${ }^{4}$ dan Al-Raaie F,dkk.(Oman, 2008) ${ }^{2}$ yang menemukan kejadian EOA lebih banyak ditemukan pada laki-laki dengan rasio yang tidak jauh berbeda. 
Berdasarkan kelompok usia, didapatkan EOA terbanyak mengenai kelompok usia 25 - 44 tahun dan paling sedikit kelompok usia 1-4 tahun. Hasil ini serupa dengan hasil penelitian Neupane S,dkk.(Nepal, $2012)^{4}$ yang menemukan kelompok usia terbanyak yang terkena EOA adalah $21-40$ tahun (52\%) dan yang paling sedikit kelompok usia $\leq 10$ tahun dan penelitian oleh Malathi M, dkk. (India, 2017) yang menemukan dari 500 kasus EOA, $62 \%$ pasien berusia lebih dari 40 tahun, sedangkan yang paling sedikit terkena berusia $0-3$ tahun $(1 \%){ }^{10}$

\section{SIMPULAN}

Pada penelitian ini, antibiotik dan antikonvulsan merupakan obat tersangka terbanyak yang menyebabkan EOA, sama seperti banyak penelitian sebelumnya. Antibiotik (cefadroxil) merupakan obat tersangka terbanyak pada kelompok makulopapular dan eritroderma. Sedangkan anti-konvulsan (karbamazepin) merupakan obat tersangka terbanyak pada kelompok SSJ.

\section{DAFTAR PUSTAKA}

1. Shear NH, Knowles SR. Cutaneous Reactions to Drugs. Dalam: Wolff $K$, Goldsmith LA, Katz SI, Gilchrest BA, Paller AS, Leffel DJ, (penyunting). Fitzpatrick Dermatology in general medicine. Edisi ke-8. New York: McGraw Hill; 2012:449-57.

2. Al-Raaie F, Banodkar DD. Epidemiological study of cutaneous adverse drug reactions in Oman. Oman Medical Journal. 2008; 23(1):17.

3. Fernandez MMC, Rosales SPL, Dubon CA, Topete RO. Incidence and risk factors for cutaneous adverse drug reactions in an intensive care unit. Rev Invest Clin. 2005; 57(6):770-4.

4. Neupane S, Sharma SR. Cutaneous Adverse Drug Reactions: A 6-month teaching hospital based study from mid-western Nepal. Journal of Clinical and Diagnostic Research 2012;6(3): 445-8.

5. Pang JYY, Pang SM, Koh HY. Cutaneous adverse drug reactions in a tertiary hospital in South-east Asia. Hong Kong J. Dermatol Venereol 2015; 23:105-12.

6. Lee HY, Martanto $\mathrm{W}$, Thirumoorthy $\mathrm{T}$. Epidemiology of Stevens-Johnson syndrome and toxic epidermal necrolysis in Southeast Asia. Dermatol Sinica. 2013; 31:217-20.

7. Rahima S, Abdul LEN, Pavithran K, Saleem PM. A clinical study of Stevens-Johnson syndrome and toxic epidermal necrolysis in a tertiary care centre, South India. Int $J$ Res Dermatol 2017; 3(1):134-9.

8. Allanore LV, Roujeau JC. Epidermal necrolysis (Stevens-Johnson syndrome and toxic epidermal necrolysis). Dalam: Wolff $\mathrm{K}$, Goldsmith LA, Katz SI, Gilchrest BA, Paller
AS, Leffel DJ, (penyunting). Fitzpatrick Dermatology in general medicine. Edisi ke-8. New York: McGraw Hill; 2012. 439-47

9. Khosama H, Budikayanti A, Khor AHP, Lim KS, Ng CC, Mansyur IG. HLA-B*1502 and carbamazepine induced Stevens-Johnson syndrome/toxic epidermal necrolysis in Indonesia. Neurology Asia 2017; 22(2): 1136.

10. Malathi M, Shanthi M, Nambi T. Adverse drug reactions at a tertiary care hospital in south india-A prospective analysis. JMSCR 2017; 5(9): 27451-6. 